\title{
Agrobacterium-Mediated Genetic Transformation and Cloning of Reference Genes in Suspension Cells of Artemisia Pallens
}

\author{
Phanikanth Jogam \\ Kakatiya University \\ Dulam Sandhya \\ Kakatiya University \\ Anshu Alok \\ Panjab University \\ Mahipal Singh Shekhawat \\ Kanchi Mamunivar Centre for Post Graduate Studies \\ Venkataiah Peddaboina \\ Kakatiya University \\ Kashmir Singh \\ Panjab University \\ Venkateswar Rao Allini ( $\sim$ vrao.alleni@gmail.com ) \\ Kakatiya University
}

Research Article

Keywords: Artemisia pallens, Agrobacterium tumefaciens, Transient transformation, GUS, Suspension cells, Reference genes.

Posted Date: March 19th, 2021

DOI: https://doi.org/10.21203/rs.3.rs-320077/v1

License: (c) (i) This work is licensed under a Creative Commons Attribution 4.0 International License. Read Full License 


\section{Abstract}

A reliable and stable Agrobacterium-mediated genetic transformation system has been developed using cell suspension cultures derived from Artemisia pallens cotyledon explants. Cotyledon, attached cotyledon, and compound leaf were found to be suitable for the induction of callus among five different types of explants tested. Yellow friable callus derived from attached cotyledon was used to initiate suspension cultures in Suspension Culture Medium (SCM) which was supplemented with 2.4-dichlorophenoxyacetic acid (2,4-D) and in combination with different concentrations of Zeatin (ZEA). Among the two different shock treatments, cold shock $\left(\right.$ at $4{ }^{\circ} \mathrm{C}$ ) for 20 minutes and heat shock $\left(a t 45^{\circ} \mathrm{C}\right.$ ) treatment for 5 minutes, heat shock treatment increased the transformation efficiency. Supplementation of chemical additives such as Silwet L-77 (0.05\%) and Pluronic F-68 (0.05\%) significantly enhanced suspension cultures' transformation efficiency. The maximum GUS intensity was recorded with an optimal intensity of blue spots in the transformed cells. The highest GUS fluorometric activity was measured as $879.4 \pm 113.7 \mathrm{nmol} 4 \mathrm{MU} / \mathrm{mg} / \mathrm{min}$ in transformed cell suspension cultures. The hygromycin-resistant callus derived from micro-calli showed intense blue colour in GUS histochemical assay. The transgene integration into the plant genome was confirmed by polymerase chain reaction (PCR) using uidA specific primers in six hygromycin-resistant cell lines. The cloned and mRNA expression levels of three candidate reference genes ADP-ribosylation factor (Arf), $\beta$-actin $(A c t)$, and ubiquitin (Ubi), and carotenoid biosynthesis pathway gene, i.e., Phytoene desaturase ( $P d s$ ) along with transgene (uidA) were evaluated in transgenic callus lines. The present Agrobacterium-mediated genetic transformation protocol could help in better understand the metabolic pathways of this medicinally important plant and its genetic improvement.

\section{Introduction}

Artemisia pallens Walls ex. DC is an important medicinal and aromatic shrub which belongs to the family Asteraceae and found mostly in south India (Pala et al. 2016). Several medicinally important Artemisia species are distributed throughout various parts of Asia, Europe, the Middle East, and North Africa (Nigam et al. 2019; Jogam et al. 2020). It is commonly known as "Davana" and shows several important medicinal properties such as anti-inflammatory, anti-pyretic, anti-microbial, antioxidant, antidiabetic, antihelmintic, anti-malarial, antiseptic, antihypertensive, antidepressant, balsamic, choleretic, digestive, depurative, diuretic, emmenagogue, insecticidal, and also used in the treatment of leukemia, wound healing, and some skin infections especially sclerosis (Suresh et al. 2011; Haider et al. 2014; Shreyas et al. 2018; Hiremath et al. 2020). It has also been used to treat measles, cough, and cold in the Indian traditional systems of medicines (Pavithra et al. 2018). The leaves and flowers of this aromatic shrub are used in decorations, making garlands, bouquets, floral decorations, and chaplets due to its rich magnificent fragrance and also in religious ceremonies (Narayana et al. 1998). The leaves and flowers are also used in the extraction of essential oil called "Davana oil." Davana oil is mainly used to prepare various food items and beverages as a flavoring agent, cosmetics, and high-grade perfumes (Mallavarapu et al. 1999; Rekha and Langer 2007; Ruikar et al. 2011).

This plant has gained considerable importance in food and pharmaceutical industries (Rekha and Langer 2007) due to the presence of several secondary metabolites, including a vital sesquiterpene lactone (artemisinin) (Mallavarapu et al. 1999; Shukla et al. 2015; Pala et al. 2016; Shreyas et al. 2018; Hiremath et al. 2020). Artemisinin and its derivatives are used to treat various diseases such as malaria, cancer, hepatitis, and schistosomiasis (Salehi et al. 2018; 2019). There is a high demand for large quantity of this plant due to its industrial importance. A substantial amount of biomass is required for the extraction and large-scale production of the compounds of interest. Initially, the artemisinin and its derivatives were extracted from aerial (mainly leaves) parts of Artemisia plants, but this process was limited due to the availability species, biomass requirement, and low product yield (<1\%) (Mannan et al. 2010). Therefore, the development and optimization of plant regeneration and genetic transformation protocols for $A$. pallens will be useful for engineering the metabolic pathway for increased production of the valuable compounds (Alok et al. 2016). Attempts have been made to develop plant regeneration system (Nathar and Yatoo 2014), Agrobacterium-mediated genetic transformation (Alok et al. 2016), induction of hairy roots using Agrobacterium rhizogenes (Pala et al. 2016) to improve this medicinally important herb.

Plant cells suspension cultures are the valuable and renewable resource of biological material that can be used for several applications, including production of potential secondary metabolites (Yue et al. 2016; Salehi et al. 2018; 2019; Santos et al. 2019). The plant cells suspension cultures are gaining popularity as a host system for the production of recombinant proteins (Tekoah et al. 2015; Yue et al. 2016) and have several advantages such as post-translational modifications, a slight risk of viral contamination, low cost of plant culture media, and cost-efficiency of bacterial expression systems (Santos et al. 2016; Zagorskaya and Deineko 2017; Permyakova et al. 2019). Metabolic engineering requires a deep understanding of its molecular and genetic architecture to produce targeted secondary metabolites successfully. Genetic and metabolic engineering in plant cell suspensions is in high demand to increase the biosynthesis of a compound of interest. The suspension cells can be developed from any explant type; however, most preferably, an embryogenic callus is used. Several successful cell suspension cultures were reported from various plants such as Artemisia annua (Salehi et al. 2019), Catharanthus (Saiman et al. 2018), 
Taxus (Wilson et al. 2018), Capsicum (Brito-Sanchez et al. 2019), Medicago (Santos et al. 2019), Arabidopsis (Permyakova et al. 2019), Gentiana (Rybczynski and Wojcik 2019), and Panicum (Ondzighi-Assoume et al. 2019).

Agrobacterium-mediated genetic transformation depends on factors like types of explants, bacterial density, co-cultivation duration, the temperature of co-cultivation, concentration of acetosyringone, etc. (Tiwari and Tuli 2012). Plant cells suspension culture is a sustainable system, but various factors may reduce the yield of product. Hence, it is necessary to develop metabolic engineering methods to optimize the production for different plant systems (Wilson et al., 2014). A reliable and stable gene transfer method must be designed for metabolic engineering of cell suspension cultures (Wilson et al., 2018), which could enable the successful utilization of suspension cultures for a wide range of studies such as molecular biology, biochemistry, and genome editing (Permyakova et al., 2019). Various factors like optical density (OD) of bacterial culture, co-cultivation time, co-cultivation temperature, silwet, pluronic concentration, acetosyringone, etc., were evaluated to develop a reliable and high-throughput stable transformation method. Apart from this, the quantification of transgene within transformed cells and other genes involved in the specific pathway would contribute to the genetic improvement of $A$. pallens. Gene expression analysis is a valuable and extensively used approach to reveal transcriptional regulatory networks, expression profiles and to identify a novel function of gene (Huggett et al. 2005; Thompson et al. 2015; Itoh et al. 2016). The candidate reference genes are ubiquitously expressed and generally involved in relatively stable expression of housekeeping processes (Thellin et al. 1999; Pfaffi et al. 2004). These genes are thought to be expressed stably in various tissues, different growth stages, and other environmental conditions. Hence, reference genes can be used to quantify the expressions of the target genes (Wang et al. 2017; 2019; Chen et al. 2019). Therefore, the quantification of gene expression using RT-qPCR requires stable reference or housekeeping genes. There is a lack of genomic or transcriptome data to the best of our knowledge in $A$. pallens, so, cloning and identification of nucleotide sequence and verification of reference genes in this plant are obligatory which can help in screening the suitable reference genes in $A$. pallens. We have cloned three candidate reference genes, i.e., ADP-ribosylation factor (Arf), $\beta$-actin (Act) and ubiquitin (Ubi), and the functional gene which involves carotenoid biosynthesis pathway, i.e., Phytoene desaturase $(P d s)$, for comparing the expression of the transgene as well as $A$. pallens genes.

In the present study, we report a reliable, stable, and high-throughput Agrobacterium-mediated genetic transformation protocol using cell suspension cultures obtained from cotyledon explants of $A$. pallens. Moreover, an attempt has been made to clone reference genes and quantify transgene in transgenic cell lines of $A$. pallens. This protocol would be starting material for future metabolic engineering studies this aromatic and highly medicinal plant.

\section{Materials And Methods}

\section{Seed sterilization, germination, and culture conditions}

Seeds of $A$. pallens were washed with tap water and kept for soaking for 2-3 hr. Surface sterilization of imbibed seeds was done using $0.1 \%$ mercuric chloride-containing water for $2 \mathrm{~min}$. The sterilized seeds were washed 3-4 times with autoclaved water under aseptic conditions to remove all traces of mercuric chloride. Seeds were spread onto Murashige and Skoog (Murashige and Skoog, 1962) agar (MSA) semisolid medium (Table 1) and kept for 2 days at $4^{\circ} \mathrm{C}$ in dark conditions for stratification. Then the plates were moved under the light for seed germination at $26 \pm 2{ }^{\circ} \mathrm{C}$ temperature.

\section{Explant preparation and callus initiation}

Newly emerged cotyledons from in-vitro grown seeds were dissected and kept for callus induction. The MS basal medium supplemented with different concentrations $\left(1,2,3 \mathrm{mg} \mathrm{L}^{-1}\right)$ of 2,4-dichlorophenoxyacetic acid (2,4-D) was tried for this experiment. In another combination, $2 \mathrm{mg} \mathrm{L}^{-1} 2,4-\mathrm{D}$ was kept constant with different concentrations of zeatin $\left(0.25,0.5\right.$, and $\left.0.75 \mathrm{mg} \mathrm{L}^{-1}\right)$ supplemented in media tested for callus induction. The attached cotyledons, individual cotyledon, compound leaf, stems, and roots were used as explants and compared to find out the best explant source (Fig. 1). The explants were kept onto the respective medium in the dark at $25 \pm 2{ }^{\circ} \mathrm{C}$. At every $18-20$ days, the fresh medium was used for subculturing of the callus.

\section{Initiation of cell suspension culture}

The friable calli were used for the initiation of suspension cells (SC) in a liquid medium. The compositions of four different SC liquid media, namely SC1, 2, 3, and 4, were tabulated in Table1. Different sets of friable calli were inoculated in 10-15 ml SC1, 2, 3, and 4 liquid media in $100 \mathrm{ml}$ flask and kept at $25 \pm 2^{\circ} \mathrm{C}$ temperature in the dark with constant shaking at $85 \mathrm{rpm}$. The cells were subcultured by replacing old liquid media with fresh medium in a sterile condition after every 8-10 days. Few suspension cell lines were discarded due to slow growth after the $4^{\text {th }}$ and $5^{\text {th }}$ subcultures. The cell lines of higher rate of multiplication were maintained in a 30-35 ml liquid medium in a $250 \mathrm{ml}$ flask. 
The Agrobacterium tumefaciens strain AGL1 has a pCambia1301 plant expression vector grown in Luria broth (LB) liquid media with appropriate antibiotics as described by Alok et al. (2016). The vector carries the $\beta$-glucuronidase gene (uidA) as a reporter marker, whereas the hygromycin phosphotransferase gene (hpt/) is a plant selectable marker. The bacterial pellet was suspended in MSL medium corresponding to $\mathrm{OD}_{600}$ 1.0. Finely filtered cells, 5-7 ml, were mixed with 5-7 ml Agrobacterium suspension, keeping final 0.D 600 0.5. The cells were allowed to co-culture for $4 \mathrm{hr}$ at $25^{\circ} \mathrm{C}$ temperature in a $50 \mathrm{ml}$ Tarson tube under dark conditions with $80 \mathrm{rpm}$ constant shaking. Cells were allowed to settle down, and the bacterial solution was removed. Cells were taken out with the help of a cell scraper and spread over Whatman filter paper. Further, this filter paper was kept onto MSA supplemented with $2 \mathrm{mg} \mathrm{L}^{-1} 2,4-\mathrm{D}$ medium and kept in the dark for 3 days at $24{ }^{\circ} \mathrm{C}$ temperature. Transformed cells were washed thrice with SC3 medium containing $250 \mathrm{mg} \mathrm{L}^{-1}$ cefotaxime. The cells were again spread on Whatman filter paper overlaid onto SM (Cef) medium (Table1). After two months, the grown micro calli were transferred onto SM $(10 \mathrm{H})$ medium (Table 1 ) with $10 \mathrm{mg} / \mathrm{L}$ hygromycin for induction of transgenic calli.

\section{Optimization of various factors for efficient transformation}

In our previous report, we optimized the effect of strains and acetosyringone on transformation efficiency, and therefore we used strain AGL1 and $200 \mu \mathrm{M}$ acetosyringone in MSL media (Alok et al., 2016). In the present study, we checked the effect of heat and cold shock to plant cells before co-culture with Agrobacterium. For heat shock, the filtered suspension cells in $50 \mathrm{ml}$ falcon were kept in a water bath for 5 min at $45^{\circ} \mathrm{C}$ temperature, and the cells were kept for $20 \mathrm{~min}$ at $4{ }^{\circ} \mathrm{C}$ temperature for a cold shock. The effect of two chemical additives, namely, Silwett L$77(0.05 \%)$ and Pluronic F-68 (0.05\%), on transient transformation was assessed. These chemical additives are well known to reduce surface tension and enhance bacterial entry into plant cells (Deguchi et al., 2020). Transformation efficiency was calculated based on GUS spots visible under a microscope in $200 \mu$ transformed SC. After optimization, all these factors were kept constant for the final transformation protocol and repeated thrice.

\section{Genomic DNA isolation and PCR of transgenic callus lines}

Transformed and untransformed calli of weight 200-300 mg were taken out from the plate for DNA isolation using the CTAB method (Doyle and Doyle, 1987). The $0.8 \%$ agarose gel was used to check the DNA quality, and quantification was done by BioSpectrometer (Eppendorf, Germany). The Polymerase Chain Reaction (PCR) was performed using 2x G9 Taq Readyload PCR master Mix (GCC Biotech, India), $10 \mu \mathrm{M}$ primers set, and 80-100 ng of DNA. The hptll and VirG specific primers were used to confirm the transgenic callus and to confirm that none of the bacteria has adhered to transgenic calli. The condition of PCR cycle was initial denaturation $94{ }^{\circ} \mathrm{C}$ for 5 min (one cycle), $94{ }^{\circ} \mathrm{C}$ for $30 \mathrm{~s}, 56$ ${ }^{\circ} \mathrm{C}$ for $30 \mathrm{~s}$, and $72{ }^{\circ} \mathrm{C}$ for $60 \mathrm{~s}$ (for 35 cycles) with a final extension at $72{ }^{\circ} \mathrm{C}$ for $5 \mathrm{~min}$. The amplified PCR products were electrophoresed in $0.8 \%$ agarose gel.

\section{GUS histochemical assay}

GUS activity of transiently transformed suspension cells and stable expression calli was performed as reported previously (Jefferson et al., 1987; Balhotia et a., 2016; Alok et al., 2020). The transformed suspension cells were kept in a 2 ml tube, and the liquid media were discarded. The $500 \mu \mathrm{l}$ X-Gluc solution [0.1\% X-Gluc (Sigma, USA), $100 \mathrm{mM} \mathrm{Na}_{2} \mathrm{HPO}_{4} \mathrm{p}^{\mathrm{H}} 7.0,0.5 \mathrm{mM}$ potassium ferricyanide, $0.5 \mathrm{mM}$ potassium ferrocyanide, $0.1 \%$ Triton $X$ and $20 \%$ Methanol] was added to the tube. The hygromycin-resistant callus was also incubated into 1 ml of $X$ Gluc solution in a $50 \mathrm{ml}$ Tarson tube. These tubes were incubated at $37^{\circ} \mathrm{C}$ for overnight in the dark. Further, cells and calli were washed with $70 \%$ ethanol. The gus activity in suspension cells was visualized under a microscope, whereas stable calli visualized by naked eyes.

\section{RNA isolation, cDNA preparation, and quantitative real-time PCR}

Total RNA was extracted from callus and suspension cells using a CTAB extraction buffer containing activated charcoal, PVPP, and $\beta$ mercaptoethanol, as described earlier by Rajakani et al. (2013). The contamination of genomic DNA was removed using NEB DNAsel as per manufacturer protocol. First-strand cDNA synthesis was carried out using an oligo-dT primer of SuperScript III reverse transcriptase (Invitrogen, USA). Quantitative real-time PCR of the uidA gene was carried out using RT-specific primers (Table $2 \mathrm{~b}$ ) of $A$. pallens Arf (ApArf), ApAct, and ApUbi as reference genes. The expression was also assessed for one of the A. pallens gene, namely the Phytoene desaturase ( $p d s)$ gene, Apart from transgene (uidA). The iTaq Universal SYBR Green Supermix (Bio-Rad, USA), with a final primer concentration of 0.3 $\mu \mathrm{M}$ forward and $0.3 \mu \mathrm{M}$ reverse using Bio-Rad CFX96 Real-Time PCR system (Bio-Rad, USA). Three biological replicates were amplified separately in real-time PCR assays. The PCR cycle was as follows: $95^{\circ} \mathrm{C}$ for $30 \mathrm{sec}$ for 40 cycles, followed by $95^{\circ} \mathrm{C}$ for 5 sec and $56^{\circ} \mathrm{C}$ for annealing and extension. The melt curve plot was done from $65^{\circ} \mathrm{C}$ to $95^{\circ} \mathrm{C}$ with a 0.5 increase in temperature at each step.

\section{Cloning of reference gene of $\boldsymbol{A}$. pallens}


Three housekeeping genes $A r f, A c t$, and $U b i$, and one $P d s$ gene were cloned using degenerate primers. The degenerate primers were designed based on conserved regions of the candidate genes from monocot and dicot plants such as Artemisia annua, Arabidopsis thaliana, Nicotiana tabacum,Solanum lycopersicum, Brachypodium distachyon, Triticum aestivum, and Oryza sativa. The accession numbers of all nucleotide sequences from Gene Bank are presented in Table 2. The PCR reaction was set up using genomic DNA as a template, degenerate primers, and Phire Hot Start II DNA Polymerase (Thermo Fisher Scientific, USA). The cycle was as followed at $98^{\circ} \mathrm{C}$ temperature for 2 min (one cycle), $98^{\circ} \mathrm{C}$ for $30 \mathrm{sec}, 55^{\circ} \mathrm{C}$ for $20 \mathrm{sec}, 72^{\circ} \mathrm{C}$ for $30 \mathrm{sec}$ (for $35 \mathrm{cycles}$ ), and a final extension at $72^{\circ} \mathrm{C}$ temperature for 2 min. The amplified PCR products were purified and ligated into pJET1.2/blunt cloning vector using CloneJET PCR Cloning Kit (Thermo Fisher Scientific, USA) as per manufacture protocol. The ligated products were then transformed into competent cells of Escherichia coli (E. coli) strain Top10. The plasmid was isolated, digested by the Bg/l restriction enzyme, and sent for sequencing.

\section{Results}

\section{Effect of explant type on callus induction}

Five different types of explants such as attached cotyledon, individual cotyledon, compound leaf, stem, and root explants were subjected to induce callus on various concentrations and combinations of media. Out of five types of explants, attached cotyledon, individual cotyledon, and compound leaf showed efficient callogenesis (Fig. 1a, b \& c). Callus initiation and formation were observed after 7-10 days of culture initiation. Whereas, stem and root did not respond, or in few cases, callus formation was noticed onto root tip. Three different types of calli were formed independently of explant types. The MS medium supplemented with 2,4-D at $2.0 \mathrm{mg} / \mathrm{L}$ was found to be the optimal concentration for callus induction from three different explants (Fig. 1e). These are morphologically distinguished as (1) a friable cream yellow (Fig. 1d), (2) soft watery and non-embryogenic type (Fig. 1f), and (3) light blackish and hard nodular type (Fig. 1g). Cent percent callus induction was found with attached or individual cotyledons, whereas leaf showed $60 \%$ of callus induction.

\section{Establishment Of Suspension Cells}

Yellow friable calli (Fig. 1d) developed from attached cotyledon were transferred to different SCM to initiate suspension cells. Most of the friable calli dispersed and proliferated into cell suspension (Fig. 2a), but few lines were not appropriately proliferated and, therefore, discarded. It was observed that $80 \%$ of the callus developed from cotyledons was developed into fast proliferating suspension cells. Whereas, friable calli produced from leaf showed lower multiplication rate and few lines were released more phenolic and due to this, the medium got blackish color. The fast and uniformly dividing cells were subcultured after every 10 days, and efficient cell suspensions were established within 3 months. When the size of cells increased more than the size of mustard seeds, it was filtered to separate fine or small cells. The fine cells were maintained for a continuous supply of suspension cells (Fig. 2b). Whereas, the filtrated, which consisted of big size cells, were discarded (Fig. 2C). Out of all four SC media, the best growth of suspension cells was observed in the SC3 medium (Table 1). Fully developed and fast multiplying cell lines were diluted by transferring of $5 \mathrm{ml}$ packed cell volume (Fig. 2d) from the old culture into $35 \mathrm{ml}$ of fresh SC medium into a $250 \mathrm{ml}$ conical flask.

\section{Factors affecting Agrobacterium-mediated transformation}

The protocol for suspension cell transformation has been optimized in present study, and the transformation was confirmed with the help of the intensity of blue coloration due to its GUS reporter gene. The GUS histochemical assay of non-transformed suspension cells did not show any color (Fig. 2e). Dark blue colored spots were noticed in suspension cells under the stereomicroscope when suspension cells were subjected to heat at $45^{\circ} \mathrm{C}$ as compared to normal transformation (Fig. 2f). Whereas, in the case of a cold shock to plant cells before coculture, the significant changes were not noticed as compared to cells transformed in normal conditions (Fig. 2h). The addition of Pluronic F$68(0.05 \%)$ in MSL medium during transformation also increased the transient transformation efficiency and showed more prominent blue spots within suspension cells (Fig. 2i). The addition of Silwett L-77 (0.05\%) in MSL medium during transformation leads to more browning of cells, which might not be suitable. However, the blue coloration was a little higher as compared to expected. The GUS intensity was lower in cells transformed without including above factors. The maximum GUS intensity was observed as more blue spots in the transformed cells, including all these factors. The GUS fluorometric activity of suspension cells transformed with bacterial solution normally (without any factor) showed $267.8 \pm 61.9 \mathrm{nmol} 4 \mathrm{MU} / \mathrm{mg} / \mathrm{min}$ activity (Fig. 3). Pluronic acid and heat significantly improved transformation efficiency, and showed $513.1 \pm 55.0$ and $626.0 \pm 32.5 \mathrm{nmol} 4 \mathrm{MU} / \mathrm{mg} / \mathrm{min}$ activity, respectively (Fig. 3). The highest GUS activity $(879.4 \pm 113.7 \mathrm{nmol}$ $4 \mathrm{MU} / \mathrm{mg} / \mathrm{min}$ ) was recorded when all optimized factors were included (Fig. 3).

\section{Development of micro calli and selection of stable calli lines}


The final transformation was done with the optimized conditions such as heat, pluronic, and 2 days co-cultivation. The transformed fine suspension cells were spread onto the Whatman filter. The cells were taken out with the help of a cells scraper and kept in SC media supplemented with $250 \mathrm{mg} \mathrm{L}^{-1}$ cefotaxime in a $50 \mathrm{ml}$ falcon tube. Washing with $250 \mathrm{mg} \mathrm{L}^{-1}$ cefotaxime for 30 min resulted in bacterial growth after 5-7 days onto plates. Whereas, washing with $250 \mathrm{mg} \mathrm{L}^{-1}$ cefotaxime and $90 \mathrm{rpm}$ constant shaking for 6 hours did not show any bacterial contamination. The increase in the concentrations of cefotaxime up to $350 \mathrm{mg} \mathrm{L}^{-1}$ and $500 \mathrm{mg} \mathrm{L}^{-1}$ with $30 \mathrm{~min}$ also unable to inhibit bacterial growth. Transformed cells were allowed to grow for two months onto SM (Cef) media having filter paper (Fig. 4a). All fine cells were grown into small yellowish creamish micro-calli after 2-3 months (Fig. 4b). This micro-calli (2-3 mm) was sifted onto SM (10H) medium with $10 \mathrm{mg} \mathrm{L}^{-1}$ hygromycin directly onto the medium without filter paper. Untransformed micro-calli were turned brown after two to three subcultures and became dead (Fig. 4c). During every subculture, the dead calli were removed from the plates. Simultaneously, the stably transformed calli were whitish and pooled (Fig. $4 \mathrm{~d}$ and e). The GUS histochemical staining of this stable calli showed intense blue color (Fig. 4f).

\section{Confirmation Of T-dna Integration}

The random screening of 6 hygromycin-resistant calli was done using uidA gene-specific primers. Agarose gel electrophoresis showed no bands in negative template PCR (L2), whereas as control, positive control plasmid PCR (L3) gave an amplification of 1500 bp amplicon. Hygromycin resistance calli also showed amplification of 1500 bp (Lane, L5 to L10) corresponding to the uidA gene, whereas no amplification was observed in non-transformed calli (L4) (Fig. 5). The VirG gene-specific primers were used to detect the presence of bacteria in hygromycin-resistant calli. All positive calli lines and control calli did not amplify VirG gene bands in PCR.

\section{Sequencing and bioinformatics analysis of reference genes}

The draft genome, transcriptome, and EST sequences were not available for A. pallens, therefore we could perform a blast search using the reference gene sequences from Arabidopsis. The PCR product sizes of the ApAct, ApArf, ApUbi reference genes, and PDS gene amplified by degenerate primers were 175, 235, 300, and 400 bp in length, respectively (Supplementary material 1a). The sequencing result of the nucleotide sequence of positive clones showed the exact sequence (Supplementary material 1b). The BLASTn of sequenced ApAct showed the highest 99\% similarity with Chrysanthemum lavandulifolium actin (JN638568.1), whereas 89.71\% similarity with Arabidopsis. ApArf showed $90.99 \%$ and $81.97 \%$ similarity with Helianthus annuus (XM_035986453.1) and Arabidopsis ADP-ribosylation factor 2, respectively. The ApUbi showed the highest similarity with Prunus mume polyubiquitin-A (XM_016792839.1), while with Arabidopsis, it showed 88.28\% similarity. The ApPDS showed $96.45 \%$ and $79.39 \%$ identity with phytoene desaturase of Chrysanthemum boreale (KC202430.1) and Arabidopsis (NM_001340908.1), respectively. All sequences were submitted to NCBI Gene Bank, and the assigned accession numbers are MW579540, MW579541, MW579542, and MW579543.

\section{Cq values of candidate reference genes and expression of UidA transgene}

The value of the quantification cycle $(\mathrm{Cq})$ represents the accumulated level of mRNA transcript in tissue. The mean Cq values of $A p U b i$, ApAct, and ApArf were 16.8, 19.0, and 21.1, respectively. The presence of a single peak also confirmed the primer specificities in melt curve analysis by RT-PCR (Fig. 6a, b, c). Further, a single DNA band confirmed these reference genes' primer specificities onto $1.5 \%$ agarose gel electrophoresis (Fig. 6d). The relative expression level for the uidA transgene and ApPDS gene were quantified according to the 2- $\triangle \mathrm{CT}$ method (Schmittgen and Livak, 2008; Alok et al., 2015). The uidA transcript mRNA of the selected callus (Line 1) was set to 1.

\section{Discussions}

Metabolic and genetic engineering in medicinal plants are in huge demand to enrich pharmaceutically important metabolites (Santos et al., 2016; Pourianezhad et al., 2019; Rodríguez-Sánchez et al., 2020). Suspension cell culture of Sophora flavescens, Taxus baccata, and Morinda citrifolia were used to produce sophoraflavanone G, taxol, and anthraquinone, respectively (Bassetti and Tramper, 1995; Kajani et al., 2010; Zhao et al., 2003). Agrobacterium-mediated genetic transformation is a more efficient and easy way of genetic transformation using different explants. Suspension cultures were successfully employed for Agrobacterium-mediated genetic transformation in several medicinally important plant species such as A. anuua (Sallets et al., 2015), Taxus sp. (Wilson et al., 2018), and Gentiana sp. (Rybczynski and Wojcik, 2019). Suspension cells can generate a large number of plants, and it has been used for various medicinal plants. $A$. pallens is an important medicinal plant in which protocols for cell suspension development and genetic transformation is still unreported. Therefore, in the current study, we optimized the best medium for suspension cell development and its Agrobacterium-mediated genetic transformation. Embryogenic calli were transparent or white friable, whereas non-embryogenic calli were blackish and globular-like structures in this case. In the present study, 2,4-D was used in SC media, and the same has been used for various other medicinal plants such as Orthosiphon 
stamineus (Wai-Leng and Lai-Keng, 2004), Peganum harmala (Khafagi, 2007), Jatropha curcas (Soomro and Memon, 2007), and A. annua (Salehi et al., 2019). Embryogenic calli grow fast as compared to the non-embryogenic calli in suspension cells and similar result was observed in case of sweet potatoes (Yang et al., 2011).

The Agrobacterium-mediated genetic transformation was dependent upon various factors affecting transformation efficiency. In our earlier report in A. pallens, the factors such as bacterial density, acetosyringone, and strains were optimized (Alok et al., 2016). The AGL1 strain for the transformation of suspension cells was used, which is a supervirulent strain and used for various crop plants such as Artemisia annua (Sallets et al., 2015), Musa spp. (Shivani et al., 2018), and Triticum aestivum (Alok et al., 2015; 2020) for transformation studies. Heat treatment before the bacterial infection could enhance the transformation capacity (Tripathi et al., 2008). Similarly, in this study, the GUS staining and specific activity were higher in heat-treated cells than the normally transformed cells (Fig. 2\&3). There were no significant changes observed in transient transformation efficiency on the addition of Silwet L-77; however, it increased GUS expression in Cannabis sp. (Deguchi et al., 2020). However, the addition of Pluronic F-68 in bacterial solution increased the GUS intensity and activity (Fig. 2 \&3). Similarly, the addition of Pluronic F-68 surfactants effectively increased the transformation efficiency in Theobroma cacao (Fister et al., 2016) and Cannabis sativus (Deguchi et al., 2020). After transformation, cefotaxime was used in the selection medium to kill adhered Agrobacterium. The overgrowth of bacteria might influence cell growth negatively. Similarly, cefotaxime is better than other antibiotics, which do not block plant regeneration in the case of sweet potatoes (Yang et al., 2011).

Transgene expression analyses are generally done by the RT-qPCR method due to their unique advantages. However, for this, a stable reference gene should be known. Due to unknown genome information of $A$. pallens, another strategy is to clone using degenerate primers. Various medicinal plants, whose reference genes were not reported, used degenerate primers (Wang et al., 2017). ApArf, ApAct, and ApUbi are the most commonly used reference genes in various plant species (Alok et al., 2015; Flowerika et al., 2016, Wang et al., 2017; 2019; Alok et al., 2020). Here, for the first time we, reported the nucleotide sequences of three reference genes from $A$. pallens. The melt curve and amplification on agarose gel showed that a single band was amplified (Fig. 6a, b, c \& d). It is crucial to select reference genes in a specific experiment and avoid using multiple genes that participate in related biological processes (Wang et al., 2017). These findings will provide more insight into suspension cell transformation and the expression profile for the transgene as well as indigenous target genes in $A$. pallens.

\section{Conclusions}

This study successfully demonstrated a reliable, stable, and transient genetic transformation of $A$. pallens using cell suspension cultures derived from cotyledonary explants with $A$. tumefaciens strain AGL1 harboring pCAMBIA1301. Transformation efficiency was enhanced by optimizing various factors like temperature, silwet, and pluronic in suspension cultures confirmed by the stable expression of the $\beta$ glucuronidase (uidA) reporter gene. Further, three candidate reference genes Arf, Act, and Ubi were cloned using degenerate primers and quantified the uidA gene expression in transgenic lines. The optimized Agrobacterium-mediated genetic transformation protocol could help better understand the metabolic pathways and improve this valuable medicinal herb.

\section{Declarations}

\section{Acknowledgments}

PJ and VRA are grateful to the University Grant Commission, New Delhi, for the financial assistance under the SAP-DRS-II program (Sanction number F-5-24/2015/DRS-II) to the Department of Biotechnology Kakatiya University, for providing research facilities. DS is thankful to the Department of Science and Technology, Government of India, for providing Inspire Fellowship (Sanction number IF160264). AA and KS are grateful to Panjab University, Chandigarh.

\section{Author Contribution}

AA and VRA conceived the idea, designed the experiments, analyzed the results, and finalized the manuscript. PJ and DS performed experiments and wrote the manuscript. KS and VRA provided the facilities and improved the manuscript. VP and MSS conceptualization, data curation, and revision of the manuscript. All authors read and approved the final manuscript.

\section{Conflict of interest}

The authors declare that they have no conflict of interest.

\section{Research involving human participant and/or animals}


No human participants and/or animals have been involved in this research.

\section{Informed consent}

No human participants have been involved in this research.

\section{References}

Alok A, Kaur H, Bhati KK, Kumar J, Pandey P, Upadhyay SK, Pandey A, Sharma NC, Pandey AK, Tiwari S (2015) Biochemical characterization and spatio-temporal expression of myo-inositol oxygenase (MIOX) from wheat (Triticum aestivum L.). Plant Gene 4:10-19

Alok A, Kaur J, Tiwari S (2020) Functional characterization of wheat myo-inositol oxygenase promoter under different abiotic stress conditions in Arabidopsis thaliana. Biotech Let 42(10):2035-2047

Alok A, Shukla V, Pala Z, Kumar J, Kudale S, Desai N (2016) In vitro regeneration and optimization of factors affecting Agrobacterium mediated transformation in Artemisia pallens, an important medicinal plant. Physiol Mol Biol Plants 22(2):261-269.

Bassetti L, Tramper J (1995) Increased anthraquinone production by Morinda citrifolia in a two-phase system with Pluronic F-68. Enzyme Microb Tech 17:353-358

Bhalothia P, Alok A, Mehrotra S, Mehrotra R (2013) AACA Element Negatively Regulates Expression of Protein Phosphatase 2C (PP2C) like Promoter in Arabidopsis thaliana. Am J Plant Sci 4:549-554

Brito-Sanchez SC, Zaragoza-Perez FA, de Jesus Olivera-Flores T, Rivero-Cruz JF, Amacosta J, Gutierrez-Luna FM, Valencia-Turcotte LG, Rodríguez-Sotres R (2019) Biolistics transformation of callus and cell suspension cultures of Capsicum annuum L.'Serrano'is useful for in vitro studies of the relative contents of secondary metabolites. Acta Agrobot 72(4):1792

Chen R, Chen W, Tigabu M, Zhong W, Li Y, Ma X, Li M (2019) Screening and Evaluation of Stable Reference Genes for Quantitative RealTime Polymerase Chain Reaction (qRT-PCR) Analysis in Chinese Fir Roots under Water, Phosphorus, and Nitrogen Stresses. Forests 10:1087

Deguchi M, Bogush D, Weeden H, Spuhler Z, Potlakayala S, Kondo T, Zhang ZJ, Rudrabhatla S (2020) Establishment and optimization of a hemp (Cannabis sativa L.) agroinfiltration system for gene expression and silencing studies. Sci Rep 10(1):1-11.

Doyle JJ, Doyle JL (1987) A rapid DNA isolation procedure for small quantities of fresh leaf tissue. Phytochem Bull 19:11-15

Fister AS, Shi Z, Zhang Y, Helliwell EE, Maximova SN, Guiltinan MJ (2016) Protocol: transient expression system for functional genomics in the tropical tree Theobroma cacao L. Plant Methods 12(1):1-13.

Flowerika AA, Kumar J, Thakur N, Pandey A, Pandey AK (2016) Characterization and expression analysis of Phytoene Synthase from Bread Wheat (Triticum aestivum L.). PLoS One 11(10):e0162443.

Haider SZ, Mohan M, Andola HC (2014) Constituents of Artemisia indica Willd. from Uttarakhand Himalaya: A source of davanone. Pharmacognosy Res 6:257-259. doi: 10.4103/0974-8490.132607

Hiremath C, Yadav MK, Gowda MRS, Kumar AN, Srinivas KVNS (2020) Influence of growth stage on essential oil content and major chemical constituents of Artemisia pallens Bess. Trends Phytochem Res 4(2):85-92.

Huggett J, Dheda K, Bustin S, Zumla A (2005) Real-time RT-PCR normalisation; strategies and considerations. Genes Imm 6(4):279-284

Itoh J, Sato Y, Hibara K, Shimizu-Sato S, Kobayashi H, Takehisa H, Sanguinet KA, Namiki N, Nagamura Y (2016) Genome-wide analysis of spatiotemporal gene expression patterns during early embryogenesis in rice. Dev 143(7):1217-1227

Jefferson RA, Kavanagh TA, Bevan MW (1987) GUS fusions: beta-glucuronidase as a sensitive and versatile gene fusion marker in higher plants. EMBO J 6:3901-3907

Jogam P, Dulam S, Shekhawat MS, Alok A, Manokari M, Abbagani S, Allini VR (2020) Genetic stability analysis using DNA barcoding and molecular markers and foliar micro-morphological analysis of in vitro regenerated and in vivo grown plants of Artemisia vulgaris L. Ind Crops

Prod 151:112476 
Kajani AA, Mofid MR, Abolfazli K, Tafreshi SAH (2010). Encapsulated activated charcoal as a potent agent for improving taxane synthesis and recovery from cultures. Biotechnol Appl Biochem, 56:71-6.

Khafagi I (2007) Generation of Alkaloid-containing idioblasts during cellula morphogenesis of Peganum harmala L. cell suspension cultures. Am J Plant Physiol 2:17-26

Mallavarapu GR, Kulkarni RN, Baskaran K, Rao L, Ramesh S (1999) Influence of plant growth stage on the essential oil content and composition in Davana (Artemisia pallens Wall.). J Agric Food Chem 47:254-258

Mannan A, Ahmed I, Arshad W, Asim AF, Qureshi RA, Hussain I, Mirza B (2010) Survey of artemisinin production by diverse Artemisia species in northern Pakistan. Malar J 9:310

Mathur S, Shekhawat GS (2013) Establishment and characterization of Stevia rebaudiana (Bertoni) cell suspension culture: an in vitro approach for production of stevioside. Acta Physiol Plant 35:931-939

Murashige T, Skoog F (1962) A revised medium for rapid growth and bioassays with tobacco tissue cultures. Physiol Plant 15:473-497 Narayana MR, Khan MNA, Dimri BP (1998) Davana and its cultivation in India, Farm Bull., No.12, CIMAP,Lucknow,11:1-10

Nathar VN, Yatoo GM (2014) Micropropagation of an antidiabetic medicinal plant, Artemisia pallens. Turk J Bot 38:491-498

Nigam M, Atanassova M, Mishra AP, Pezzani R, Devkota HP, Plygun S, Salehi B, Setzer WN, Sharifi-Rad J (2019) Bioactive Compounds and Health Benefits of Artemisia Species. Natural Product Comm : 1-17

Ondzighi-Assoume CA, Willis JD, Ouma WK, Allen SM, King Z, Parrott WA, Liu W, Burris JN, Lenaghan SC and Stewart Jr NC (2019) Embryogenic cell suspensions for high-capacity genetic transformation and regeneration of switchgrass (Panicum virgatum L.). Biotechnol Biofuels 12:290

Pala Z, Shukla V, Alok A, Kudale S, Desai N (2016) Enhanced production of an anti-malarial compound artesunate by hairy root cultures and phytochemical analysis of Artemisia pallens Wall. 3Biotech 6:182

Pavithra KS, Annadurai J, Ragunathan R (2018) Phytochemical, antioxidant and a study of bioactive compounds from Artemisia pallens. J Pharmacog Phytochem 7(4): 664-675

Permyakova NV, Sidorchuk YV, Marenkova TV, Khozeeva SA, Kuznetsov VV, Zagorskaya AA, Rozov SM, Deineko EV (2019) CRISPR/Cas9-mediated gfp gene inactivation in Arabidopsis suspension cells. Mol Biol Rep 46:5735-5743

Pfaffl MW, Tichopad A, Prgomet C, Neuvians TP (2004) Determination of stable housekeeping genes, differentially regulated target genes and sample integrity: Best Keeper - Excel-based tool using pair-wise correlations. Biotech Let 26:509-515.

Pourianezhad F, Rahnama H, Mousavi A, Khosrowshahli M, Mafakheri S (2019) Parthenolide production in cell suspension culture of feverfew. Biores Bioproc 6(1):1-7

Rajakani R, Narnoliya L, Sangwan NS, Sangwan RS, Gupta V (2013) Activated charcoal-mediated RNA extraction method for Azadirachta indica and plants highly rich in polyphenolics, polysaccharides and other complex secondary compounds. BMC Res Notes 6(1):1-10.

Rekha K, Langer A (2007) Induction and assessment of morpho-biochemical mutants in Artemisia pallens Bess. Genet Resour Crop Evol $54: 437-443$

Rodriguez-Sanchez LK, Perez-Bernal JE, Santamaria-Torres MA, Marquinez-Casas X, Cuca-Suarez LE, Prieto-Rodriguez JA, Patino-Ladino OJ (2020) Effect of methyl jasmonate and salicylic acid on the production of metabolites in cell suspensions cultures of Piper cumanense (Piperaceae). Biotech Rep 28:e00559.

Ruikar AD, Khatiwora E, Ghayal NA, et al (2011) Studies on aerial parts of Artemisia pallens wall for phenol, flavonoid and evaluation of antioxidant activity. J Pharm Bioallied Sci 3:302-305

Ruikar AD, Khatiwora E, Ghayal NA, Misra AV, Mujumdar AM, Puranik VG, Deshpande NR (2011) Studies on aerial parts of Artemisia pallens wall for phenol, flavonoid and evaluation of antioxidant activity. J Pharm Bioallied Sci 3:302-305 
Rybczynski JJ, Wojcik Al (2019) The effect of L-glutamine on the genetic transformation of embryogenic cell suspensions of gentian species (Gentiana lutea L., Gentiana cruciata L., and Gentiana kurroo Royle) using Agrobacterium tumefaciens. BioTech 100(1):5-18

Saiman MZ, Miettinen K, Mustafa NR, Choi YH, Verpoorte R, Schulte AE (2018) Metabolic alteration of Catharanthus roseus cell suspension cultures overexpressing geraniol synthase in the plastids or cytosol Plant Cell Tiss Org Cult 134:41-53

Salehi M, Karimzadeh G, Naghavi MR, Badi MR, Monfared SR (2018) Expression of artemisinin biosynthesis and trichome formation genes in five Artemisia species. Ind Crops Prod 112:130-140

Salehi M, Karimzadeh G, Naghavi MR (2019) Synergistic effect of coronatine and sorbitol on artemisinin production in cell suspension culture of Artemisia annua L. cv. Anamed. Plant Cell Tiss Org Cult 137(3):587-597

Sallets A, Delimoy A, Boutry M (2015) Stable and transient transformation of Artemisia annua suspension cells. Plant Cell Tiss Organ Cult 120:797-801

Santos RB, Pires AS, van der Hoorn RAL, Schiermeyer A, Abranches R (2019) Generation of transgenic cell suspension cultures of the model legume Medicago truncatula: a rapid method for Agrobacterium mediated gene transfer. Plant Cell Tiss Org Cult 136:445-450

Santos RB, Abranches R, Fischer R, Sack M, Holland T (2016) Putting the spotlight back on plant suspension cultures. Front Plant Sci 7:297 Schmittgen TD, Livak KJ (2008) Analyzing real-time PCR data by the comparative $\mathrm{C}_{\mathrm{T}}$ method. Nature Prot 3:1101-1108.

Shivani, Awasthi P, Sharma V, Kaur N, Kaur N, Pandey P, Tiwari S (2017) Genome-wide analysis of transcription factors during somatic embryogenesis in banana (Musa spp.) cv Grand Naine. Plos One 12, e0182242.

Shreyas RM, Mamatha KM, Suma US (2018) A review on phytoconstituents and medicinal uses of Dhavana. Asian J Res Chem Pharm Sci. 6(4): 202-205

Shukla V, Pala Z, Alok A, Desai N (2015) Screening of different Artemisia spp. from Western Ghats of Maharashtra for an Anti-Malarial compound-Artemisinin. Am J Plant Sci 6:1619-1632

Soomro R, Memon RA (2007) Establishment of callus and suspension culture in Jatropha curcas. Pak J Bot 39:2431-2441

Suresh J, Singh A, Vasavi A, Ihsanullah M and Mary S (2011) Phytochemical and pharmacological properties of Artemisia pallens. Int. J Pharm. Sci. Res. 2(12):3081-3090

Tekoah Y, Shulman A, Kizhner T, Ruderfer I, Fux L, Nataf Y, Bartfeld D, Ariel T, Gingis-Velitski S, Hanania U and Shaaltiel Y (2015) Large-scale production of pharmaceutical proteins in plant cell culture-the protalix experience. Plant Biotech J 13:1199-1208.

Thellin O, Zorzi W, Lakaye B, De Borman B, Coumans B, Hennen G, Grisar T, Igout A, Heinen E (1999) Housekeeping genes as internal standards: use and limits. J Biotech 75(2):291-295

Thompson D, Regev A, Roy S (2015) Comparative analysis of gene regulatory

\section{Tables}

Table 1. Different media and composition 


\begin{tabular}{|c|c|}
\hline $\begin{array}{l}\text { Name of } \\
\text { Media }\end{array}$ & Composition of media \\
\hline MSA & $4.33 \mathrm{~g} / \mathrm{L}$ Murashige and Skoog basal salts, $3 \%(\mathrm{w} / \mathrm{v})$ sucrose, $0.8 \%(\mathrm{w} / \mathrm{v})$ agar, $\mathrm{pH} 5.8(\mathrm{KOH})$ \\
\hline SC1 & $4.33 \mathrm{~g} / \mathrm{L}$ Murashige and Skoog basal salts, $3 \%(\mathrm{w} / \mathrm{v})$ sucrose, $2 \mathrm{mg} / \mathrm{L} 2,4 \mathrm{D}$, and $0.8 \%(\mathrm{w} / \mathrm{v})$ agar, $\mathrm{pH} 5.6(\mathrm{KOH})$ \\
\hline SC2 & $\begin{array}{l}4.33 \mathrm{~g} / \mathrm{L} \text { Murashige and Skoog basal salts, } 3 \text { \% (w/v) sucrose, } 2 \mathrm{mg} / \mathrm{L} 2,4 \mathrm{D}, 5 \mathrm{mg} / \mathrm{L} \text { Ascorbic acid, and } 0.8 \% \text { (w/v) agar, } \\
\mathrm{pH} 5.6(\mathrm{KOH})\end{array}$ \\
\hline SC3 & $\begin{array}{l}\text { 4.33 g/L Murashige and Skoog basal salts, } 3 \%(\mathrm{w} / \mathrm{v}) \text { sucrose, } 2 \mathrm{mg} / \mathrm{L} 2,4 \mathrm{D}, 0.25 \mathrm{mg} / \mathrm{L} \text { Zeatin, } 5 \mathrm{mg} / \mathrm{L} \text { Ascorbic acid, and } \\
0.8 \%(\mathrm{w} / \mathrm{v}) \text { agar, pH } 5.6(\mathrm{KOH})\end{array}$ \\
\hline sc4 & $\begin{array}{l}4.33 \mathrm{~g} / \mathrm{L} \text { Murashige and Skoog basal salts, } 3 \%(\mathrm{w} / \mathrm{v}) \text { sucrose, } 2 \mathrm{mg} / \mathrm{L} 2,4 \mathrm{D}, \mathrm{mg} / \mathrm{L} 0.5 \text { Zeatin, 5mg/L Ascorbic acid, and } \\
0.8 \%(\mathrm{w} / \mathrm{v}) \text { agar, pH } 5.6(\mathrm{KOH})\end{array}$ \\
\hline MSL & $4.33 \mathrm{~g} / \mathrm{L}$ Murashige and Skoog basal salts, $20 \mathrm{mg} / \mathrm{L}$ glucose, $195.2 \mathrm{mg} / \mathrm{L} \mathrm{MES}, \mathrm{pH} 5.6(\mathrm{KOH})$ \\
\hline SM(Cef) & $\begin{array}{l}4.33 \mathrm{~g} / \mathrm{L} \text { Murashige and Skoog basal salts, } 3 \%(\mathrm{w} / \mathrm{v}) \text { sucrose, } 2 \mathrm{mg} / \mathrm{L} 2,4 \text { D, } 0.25 \mathrm{mg} / \mathrm{L} \text { Zeatin, } 250 \mathrm{mg} / \mathrm{L} \text { cefotaxime, } 0.8 \\
\%(\mathrm{w} / \mathrm{v}) \text { agar, } \mathrm{pH} 5.85(\mathrm{KOH})\end{array}$ \\
\hline $\mathrm{SM}(10 \mathrm{H})$ & $\begin{array}{l}4.33 \mathrm{~g} / \mathrm{L} \text { Murashige and Skoog basal salts, } 3 \%(\mathrm{w} / \mathrm{v}) \text { sucrose, } 2 \mathrm{mg} / \mathrm{L} 2,4 \mathrm{D}, 0.2 \mathrm{mg} / \mathrm{L} \text { Zeatin, } 10 \mathrm{mg} / \mathrm{L} \text { hygromycin , } 250 \\
\mathrm{mg} / \mathrm{L} \text { cefotaxime, } 0.8 \%(\mathrm{w} / \mathrm{v}) \text { agar, } \mathrm{pH} 5.8(\mathrm{KOH})\end{array}$ \\
\hline
\end{tabular}

Table 2a: Degenerate primers of reference genes for cloning in A. pallens.

\begin{tabular}{|llll|}
\hline Genes & Forward primer sequence & Reverse primer sequence & Amplicon size \\
\hline ApAct & 5'AYGAYATGGARAARATHTGGCAYCAY3' & 5'GCYTGRATRGCVACATACATRGCHGG3' & $175 \mathrm{bp}$ \\
\hline ApArf & 5'AATGAYMGRGABCGYGTTGTKGARGC3' & 5'RCCARTCMAGVCCYTCRTAVARH3' & $235 \mathrm{bp}$ \\
\hline ApUbi & 5'AAGCARCTKGARGAYGGMMGNACYY3' & 5'RVACMARRTGVARSGTBGAYTCYTT3' & $300 \mathrm{bp}$ \\
\hline ApPDS & 5'ARGATGAWGATGGNGAYTGGTAYGA3' & 5'GCCTTKGACATDGCAATRAAMACCTCR3' & $400 \mathrm{bp}$ \\
\hline
\end{tabular}

Table 2b: RT-PCR primers of used for real time expression of transgene in $A$. pallens.

\begin{tabular}{|lll|}
\hline Genes name & Forward primer sequence & Reverse primer sequence \\
\hline ApAct & 5'GGCATCACACTTTCTACAACGAGC3' & 5'CCTGGATGGCAACATACATAGCG3' \\
\hline ApArf & 5'GGGAACGTGTTGTTGAGGCAAG3' & 5'CCCTCGTACAGTCCTTCGCCAG3' \\
\hline ApUbi & 5'GGAATCGACCCTCCATTTGGTTC3' & 5'GTCAGCAAGGGTACTTCCATCCT3' \\
\hline ApPDS & 5'CTGCCTGCACCACTCAATGGAA3' & 5'CACCTCAGTCGTAACTCGATCC3' \\
\hline UidA_RT & 5'AGGGCCTCGGAAAAGTCATTCGT & 5'CCCGGTTGGGCCATTGAAGTC3' \\
\hline UidA & 5'TACCCGATCAACACCGAGACCCG3' & 5'CCACGCGTGAAATTCCTGGCGG3' \\
\hline
\end{tabular}

Table 2C: Accession numbers of reference and PDS genes in different plants in Gene Bank. 


\begin{tabular}{|clllllll|}
\hline Genes & $\begin{array}{l}\text { Arabidopsis } \\
\text { thaliana }\end{array}$ & $\begin{array}{l}\text { Nicotiana } \\
\text { Tobaccum }\end{array}$ & $\begin{array}{l}\text { Solanum } \\
\text { lycopersicum }\end{array}$ & $\begin{array}{l}\text { Artemisia } \\
\text { annua }\end{array}$ & $\begin{array}{l}\text { Brachypodium } \\
\text { distachyon }\end{array}$ & $\begin{array}{l}\text { Triticum } \\
\text { aestivum }\end{array}$ & Oryza sativa \\
\hline ApAct & NM_121018 & XM_016658880 & NM_001330119.1 & EU531837.1 & XM_003574140.4 & AK457872 & XM_015759418 \\
\hline ApArf & NM_001331919 & XM_016584354 & XM_026030464 & Not found & XM_003557321 & AK446928 & XM_015791548 \\
\hline ApUbi & NM_001084884 & XM_016597143 & NM_001345879 & EU258763 & XM_003574817 & AK446626 & XM_015780523 \\
\hline ApPDS & NM_001340907 & XM_016642616 & XM_019212594 & KM892862 & XM_010230778 & FJ517553 & XM_015777615 \\
\hline
\end{tabular}

\section{Figures}
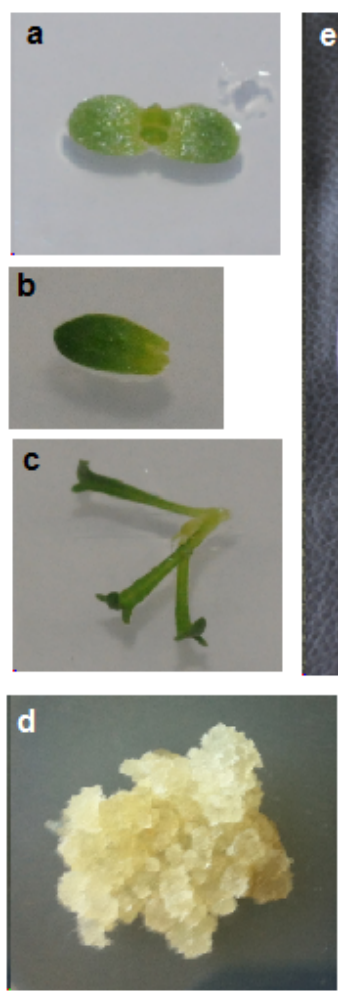
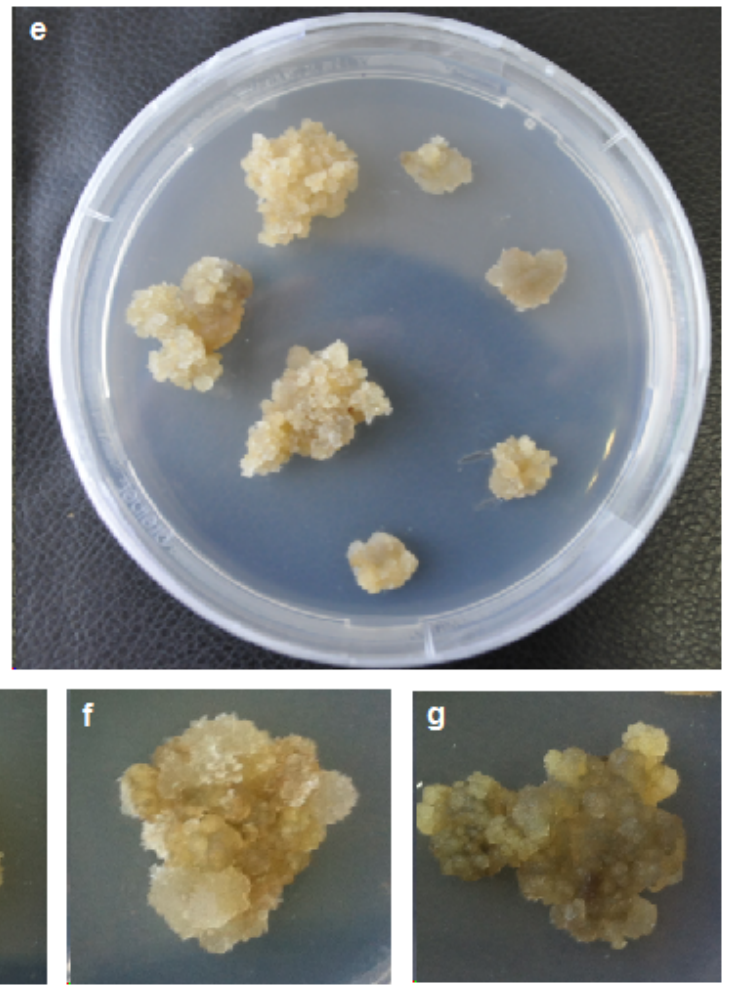

Fig 1

Figure 1

Callus induction from different explants of Artemisia pallens on MS medium supplemented with 2,4-D (2. 0 mg L-1). (a) attached cotyledon explant, (b) individual cotyledon explant, (c) compound leaf explant, (d) friable cream yellow callus, (e) 2 months old calli onto medium obtained from cotyledon explant, (f) non-embryonic callus, and (g) hard nodular callus. 

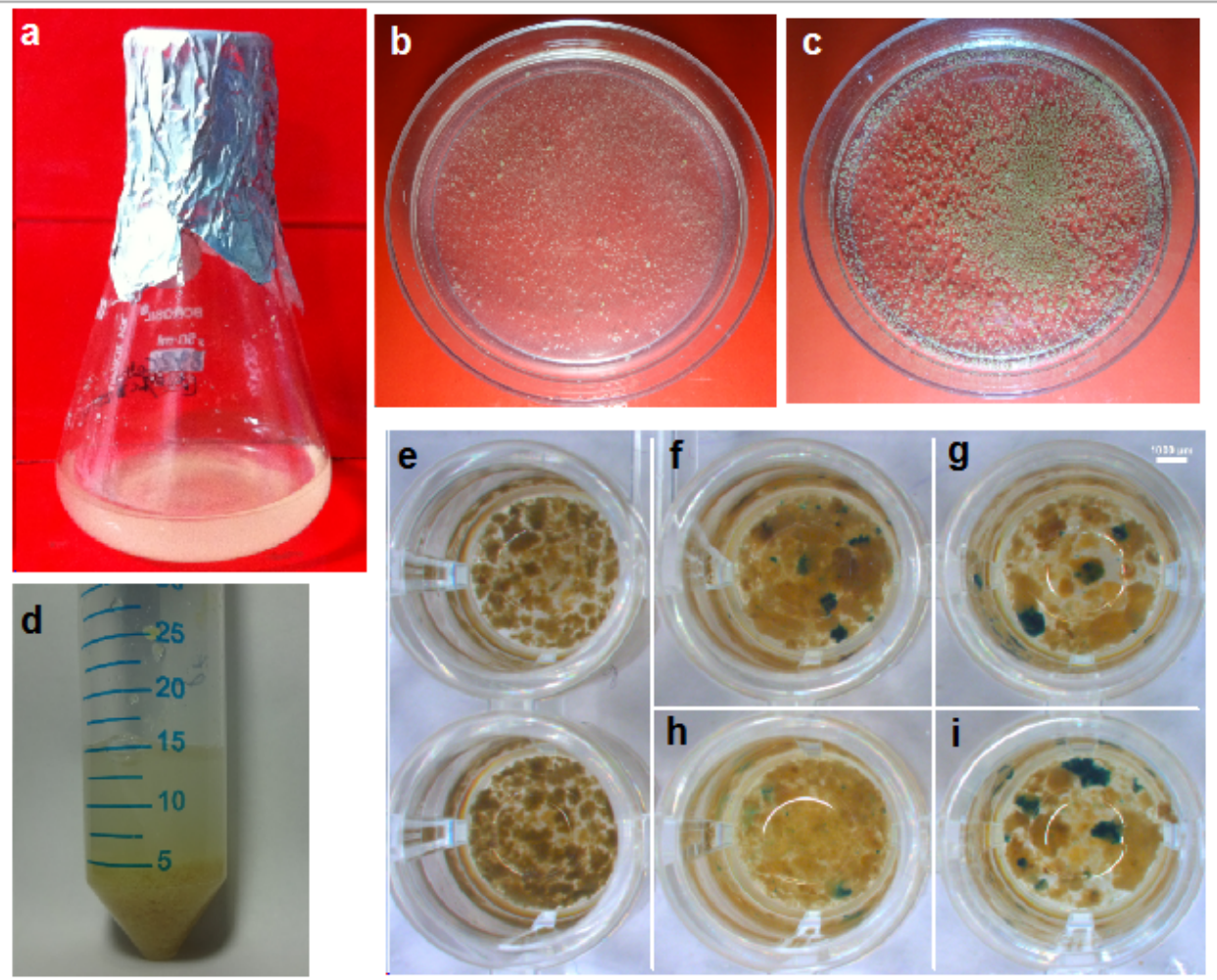

Fig 2

\section{Figure 2}

Initiation and proliferation of suspension cultures from callus derived from cotyledon explants of Artemisia pallens on MS medium supplemented with 2,4-D (2.0 mg L-1) and ZEA (0.25 mg L-1). (a) Initiation of suspension cultures, (b) proliferated fine cells after two to three months of cultures initiation, (c) filtered suspension cells or clumps, (d) transformation of suspension cultures with Agrobacterium tumefaciens, (e) non-transformed suspension cells and micro-calli (control) after gus histochemical assay, (f) transformed suspension cells and micro-calli showing blue color after gus histochemical assay, (g) effect of temperature on gus histochemical assay, (h) effect of cold shock on gus histochemical assay, and (h) effect of pluronic acid F-68 on gus histochemical assay,

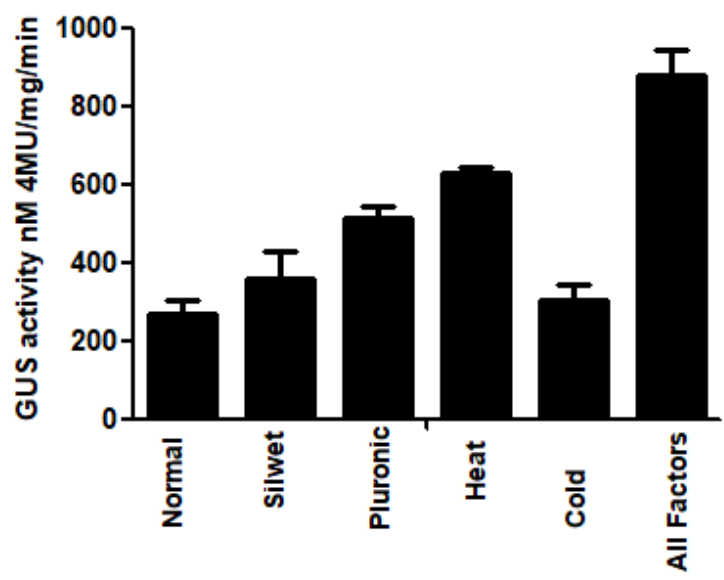

Figure 3

Effect various factors on GUS fluorometric activity $\mathrm{nmol}(4 \mathrm{MU} / \mathrm{mg} / \mathrm{min})$ of suspension cells transformed with Agrobacterium tumefaciens. 

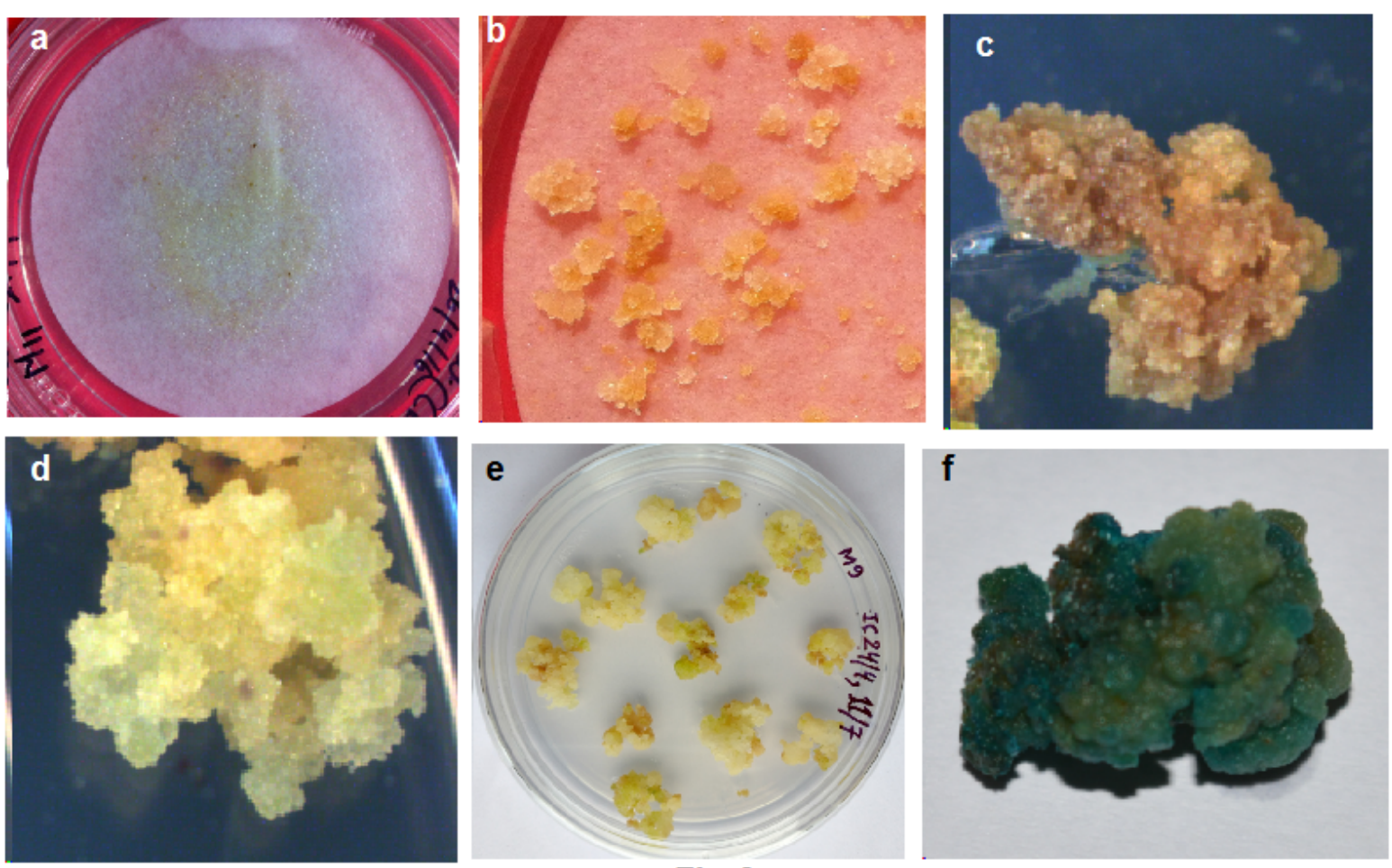

Fig 3

Figure 4

Proliferation of transformed suspension cultures and development of micro-calli of Artemisia pallens. (a) transformed cells onto filter paper, (b) yellowish and creamish micro calli after 3 months of cultures, (c) untransformed calli dead after two to three subcultures on selection medium, ( $\mathrm{d}$ and e) transformed micro-calli on selection medium after two to three subcultures, and (f) transformed micro-calli showing blue color in gus histochemical assay.

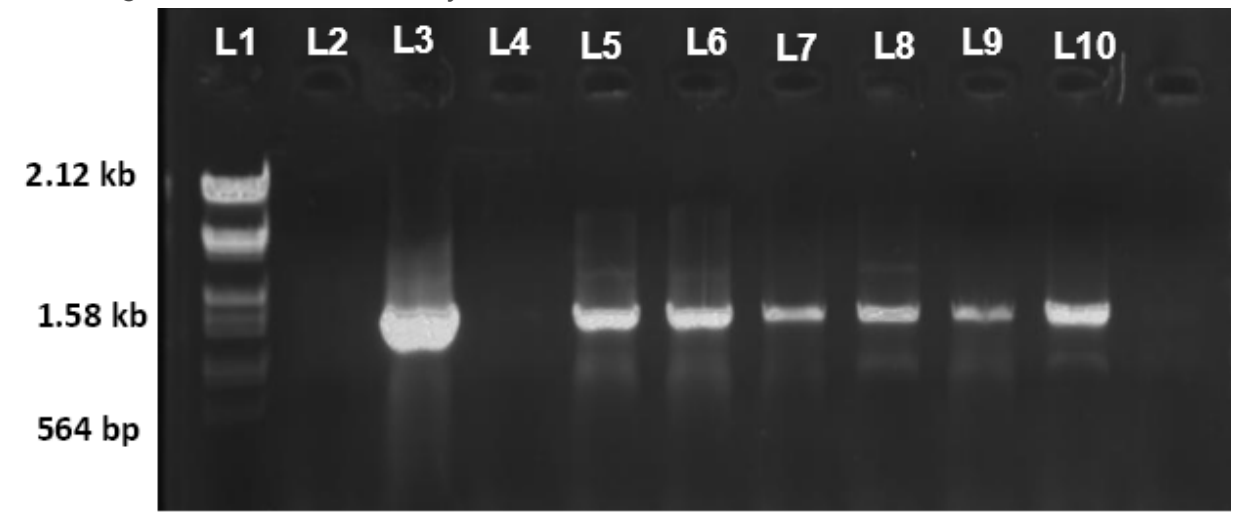

\section{Figure 5}

Molecular confirmation of transgenic callus lines Artemisia pallens analysis for gusA gene presence in hygromycin-resistant callus lines using gusA gene-specific primers. L1: Marker DNA ladder (2.12 kb ladder, Thermo Scientific); L2: No template (Negative control); L3: Positive control (plasmid DNA); L4: Wild type (control plant DNA); L5-L10: Hygromycin resistant callus lines 


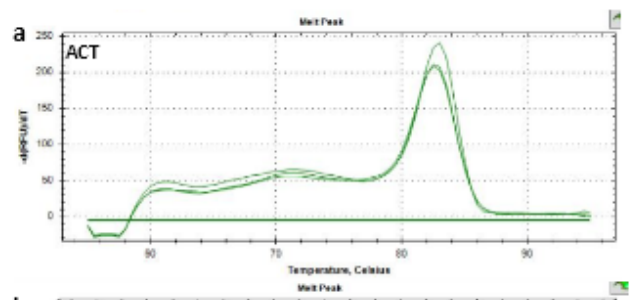

d

L1 L2 L3 L4 L5 L6
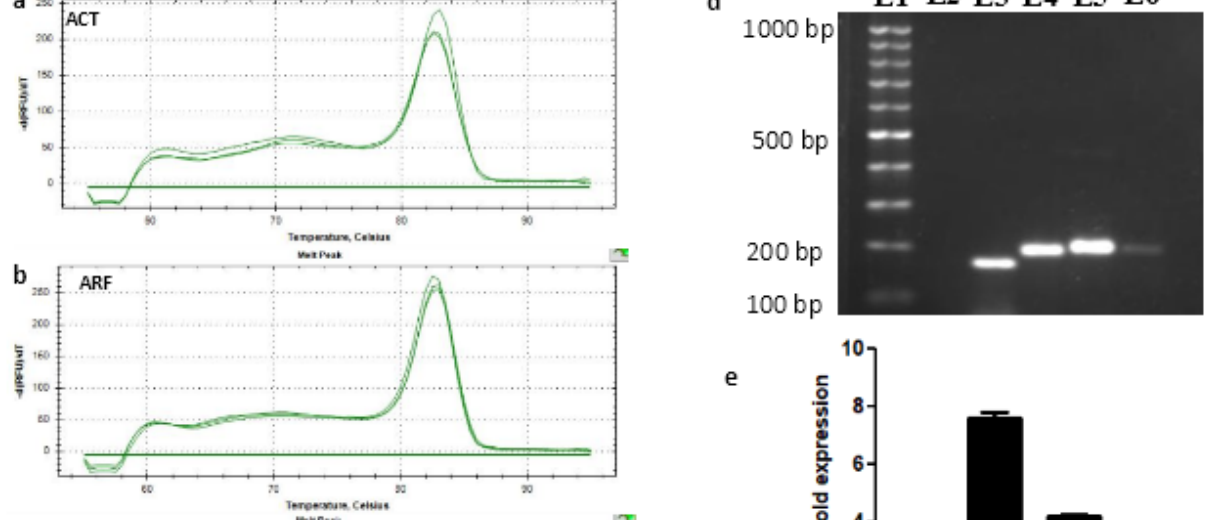

e

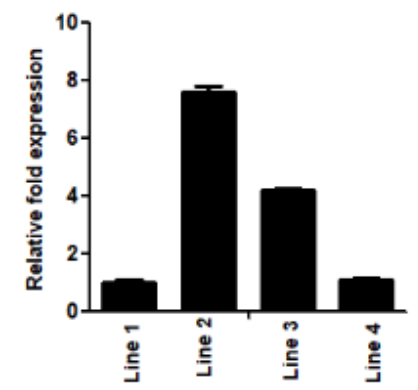

\section{Figure 6}

Confirmation for the presence of a single peak in melt curve analysis by RT-PCR. Melt curves of 3 candidate reference genes showing single peaks (a) ApAct ( $\beta$-actin), (b) ApArf (ADP-ribosylation factor), (c) ApUbi (ubiquitin) (d) L1: 100 bp DNA ladder, L2: No template (Negative control), L3: ApAct, L4: ApArf, L5: ApUbi, and L6: Appds (e) the relative expression of uidA gene in transgenic callus lines of Artemisia pallens.

\section{Supplementary Files}

This is a list of supplementary files associated with this preprint. Click to download.

- groupimage3.png 